\title{
Hydrobiological Study of the Yamuna River at Kalpi, District Jalaun, Uttar Pradesh, India
}

Dr. Manoj Kumar, Dr. P. K. Khare and Dr. Ravindra Singh

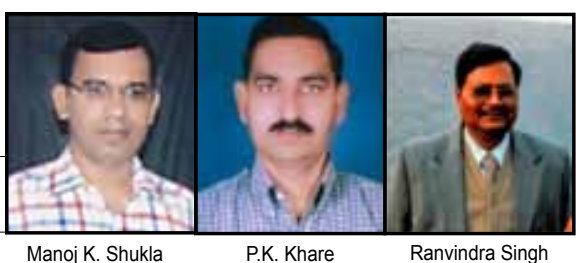

Abstract: Hydro biological study of the Yamuna river at Kalpi in India was carried out for a period of twelve month (October 2013 to September 2014). Four sampling stations were selected for sampling purpose. Collected samples were evaluated for fourteen physico-chemical parameters such as W.T., pH, Conductivity, Turbidity, T.D.S., T.H., T.A., Cl, SO4, PO4, NO3, D.O., B.O.D. and C.O.D. and four biological parameters such as phytoplankton, zooplankton, aquatic macrophytes and fishes. Present study reveals that water quality of the Yamuna river was not fit for drinking purpose but it was satisfactory for fish culture and irrigation purpose. Presence of both pollution tolerant and pollution intolerant species of biological parameters shows that this water was moderately polluted during course of study.

Keywords: Yamuna river, Physico-chemical parameters, Biological parameters, Kalpi, India

\section{Introduction}

$\mathrm{W}$ ater is the most vital resource for all kinds of life on planet. Although water covers $71 \%$ of the total surface area of the earth but hardly $1 \%$ is available as fresh water. Rivers, dams, lakes, reservoirs, ponds, tanks, streams and other small water bodies are important part of fresh water system of the earth.

Rivers are significant natural sources of water, which are being used for different life supporting activities. In spite of multifarious uses, unfortunately rivers are being used as receptacles for sewage and industrial wastes. Today most of the rivers have become polluted to a great extent by domestic sewage and industrial wastes (Shukla et al., 1989 and Singh and Ghosh, 1999). Pollution of water bodies ultimately affecting aquatic flora and fauna and causing serious diseases to human beings.

Yamuna, the largest tributary of river Ganga, is famous and holy river of India, flows from Yamunotri (Uttrakhand) to Allahabad (Uttar Pradesh) with covering a distance of $1376 \mathrm{~km}$. Now, facing a serious problem of pollution due to unplanned urbanization and industrialization.

Now a day, water quality has become a major concern due to ever increasing human developmental activities that over exploit and pollute the water resources. The assessment of the changes in river communities as a result of the impact of pollution is particularly interesting issue because running water is becoming increasingly affected by anthropogenic discharges (Whitton et al., 1991).

Considering the importance of rivers as fresh water resources, a number of hydrobiological studies have been conducted (Bodola and Singh, 1981; Shukla et al., 1989; Agrawal and Trivedi, 1995; Singh and Gosh, 1999; Sengupta, 2006; Singh and Singh, 2007; Sharma et al., 2008; Mishra et al., 2009; Alam, 2013 and Chandra et al., 2014).

\section{Aim and Objectives}

Objectives of this study was to conduct analysis of 14 selected physico-chemical parameters and compare with maximum permissible limit for drinking water as recommended by W.H.O. and to analysis four biological parameters of the Yamuna river at Kalpi stretch and, thus, conclude hydrobiological features and pollution status of this river.

\section{Material and Methods}

Study Area: The study was carried out at Kalpi stretch of the Yamuna river. Kalpi is a historical city of district Jalaun of Uttar Pradesh in India. It is located in between Jhansi and Kanpur on NH-25 and $30 \mathrm{~km}$. away from district headquater Orai. It lies to the south east bank of Yamuna and falls under $26^{\circ} 7^{\prime} 14^{\prime \prime}$ $\mathrm{N}$ latitude to $79^{\circ} 44^{\prime} 59^{\prime \prime}$ E longitude with an average elevation of 112 meters, $5 \mathrm{~km}$ length of Yamuna at Kalpi from vicinity of Vyas Mandir (u/s) to Raid drain opening $(d / s)$ was under study programme (Figure 1, 2 and 3 ).

Sampling and Analysis: Four sampling stations named as S1- vicinity and in front of Vyas Mandir, S2- Kila Ghat, S3- Peela Ghat and $\mathrm{S}_{4}$ - near Raid drain opening were selected for the sampling purpose (Figure. 3). Four drains named as D1 (Jondhar drain), D2 (small drain), D3 (Sua Baba drain) and S4 (Raid drain) were being open into the Yamuna at study area.

The samples were collected monthly till one year (October 2013 to September 2014) from selected sampling stations.

For physico-chemical parameters, water samples were collected in plastic bottles of two litre capacity. After collection, samples were properly packed and transported to laboratory in the same day to avoid any changes. Separate BOD bottles were used for sample collection for DO and BOD analysis. Water samples were kept in darkness at $4^{\circ} \mathrm{C}$ till analysis in laboratory.

Water temperature was measured by thermometer and $\mathrm{pH}$ was measured by pen $\mathrm{pH}$ meter at sampling site. Other parameters like Conductivity, Turbidity, T.D.S., T.H., T.A., $\mathrm{Cl}, \mathrm{SO}_{4}, \mathrm{PO}_{4}, \mathrm{NO}_{3}$, D.O., B.O.D. and C.O.D. were analysed in the laboratory according to the standard methods (APHA, 2005; Trivedi and Goel, 1986 and Adoni, 1985).

Plankton samples were collected between 8.0 am to 9.30 am at every selected sampling stations. Plankton net of bolting silk no. 25 was used for sampling purpose. Samples were taken at mid stream 0.5 to 1 $\mathrm{m}$ below the surface of water. Collected concentrated plankton samples $(10 \mathrm{ml})$ were fixed and preserved in $5 \%$ formalin. 
Plankton samples were examined under high power microscope and identified up to genus and species level with the help of standard books and monographs (Prescott, 1962 and Adoni, 1985 for Phytoplankton and Adoni, 1985 and Battish, 1992 for Zooplankton).

\section{Result and Discussion}

Physico-chemical Parameters: Observed selected 14 physico-chemical parameters were tabulated and analysed to understand the physico-chemical characteristics of studied water sample. Average value of recorded physico-chemical parameters of 4

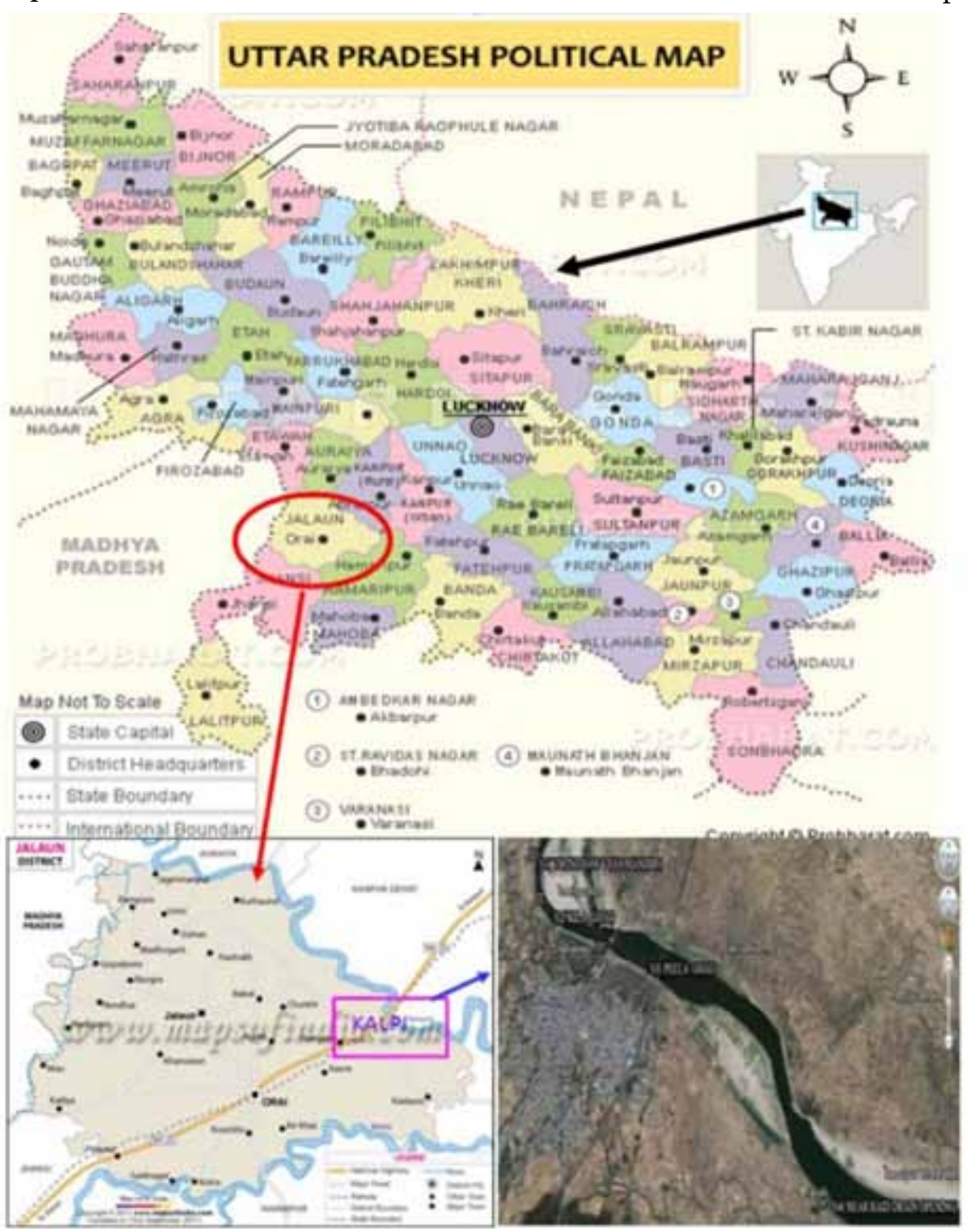
sampling sites were tabulated and compared with maximum permissible limit of drinking water (as given by W.H.O.). Data has given in Table No. 1.

Water Temperature $(\boldsymbol{W} \cdot \boldsymbol{T}):. \mathrm{M}$ a $\mathrm{x}$ i $\mathrm{m} \mathrm{u} \mathrm{m}$ t e m perature $\left(31.5{ }^{\circ} \mathrm{C}\right)$ was recorded in June and minimum temperature (15.5 ${ }^{\circ} \mathrm{C}$ ) in month of January, with average temperature was 25.38 ${ }^{\circ} \mathrm{C}$. Temperature was suitable for the survival and growth of fish fauna.

$\boldsymbol{p H}$ : The $\mathrm{pH}$ value was in the range from 7.60 to 8.70 . The maximum $\mathrm{pH}$ value 8.70 was recorded in the month of June and minimum 7.60 in the month of January with average value of 8.28. Recorded $\mathrm{pH}$ was higher in most of the time than the permissible limit of WHO for drinking water (i.e, 6.5 to 8.5 ) but it was under the limit for fish culture (i.e., 6.0 to 9.0) and irrigation purpose (i.e, 5.5 to 9.0). pH of Yamuna river was alkaline in nature.

Conductivity: Conductivity was recorded in the range of $330 \mu \mathrm{S} / \mathrm{cm}$ to $1060 \mu \mathrm{S} / \mathrm{cm}$ during study period. It was minimum in August month and maximum in June month. The average value of recorded Conductivity was $601.25 \mu \mathrm{S} /$

Figure No 1: Map of U.P. express location of district Jalaun Figure No 2: Map of district Jalaun

Figure No 3: Satellite photograph of whole Study Area (Yamuna river at Kalpi)

Aquatic macrophytes were collected from inside and surrounding of the Yamuna river at all selected sampling sites in all seasons during study span. They were collected by long handled iron hook from different types of habitate. Collected macrophytes were identified up to genus and species level with the help of pertinent literature.

Fish fauna were collected at every selected sampling sites in all seasons of study period by using net of various mesh size. Collected fishes were identified up to genus and species level with the help of standard books and monographs (Jhingran, 1992 and Jayram, 2010). $\mathrm{cm}$. Registered value of conductivity was more than the prescribed limit of WHO for drinking water (i.e., $300 \mu \mathrm{S} / \mathrm{cm}$ ).

Turbidity: Value of Turbidity was in range 26.0 to 200 NTU. Minimum value of turbidity was recorded in the month of February while maximum value in August. Mean value of turbidity was 83.58 NTU. Observed turbidity value was found to be greater than prescribed limit of WHO for drinking water (i.e., 5 NTU).

\section{Where, W.H.O. = World Health Organization}

Total Dissolved Solid (T.D.S.): The value of T.D.S. was in range from 458 to $675 \mathrm{mg} / \mathrm{L}$. Minimum value of T.D.S. was recorded in January month and maximum value in August while average value was $564.58 \mathrm{mg} / \mathrm{L}$. In most time, noticed T.D.S. value range was more than the limit recommended by WHO 
for drinking water (i.e., $250 \mathrm{mg} / \mathrm{L}$ to $600 \mathrm{mg} / \mathrm{L}$ ).

Total Hardness (T.H.): Recorded total hardness of the Yamuna water was in the range of $84.5 \mathrm{mg} / \mathrm{L}$ (minimum) to $148.9 \mathrm{mg} / \mathrm{L}$ (maximum). Minimum hardness was recorded in the August month while maximum hardness in the June month. Average of recorded hardness was $111.48 \mathrm{mg} / \mathrm{L}$. Recorded hardness value was under the prescribed limit of WHO for drinking water (i.e., max. $500 \mathrm{mg} / \mathrm{L}$ ).

\begin{tabular}{|c|c|c|c|c|c|}
\hline S.NO. & $\begin{array}{l}\text { Physico- } \\
\text { chemical } \\
\text { Parameters }\end{array}$ & Minimum & Maximum & Mean & $\begin{array}{c}\text { Maximum } \\
\text { permissible } \\
\text { limit for } \\
\text { drinking } \\
\text { water (WHO) }\end{array}$ \\
\hline 1 & Water Temp. $\left({ }^{\circ} \mathrm{C}\right)$ & 15.5 Jan. & 31.5 Jun. & 25.38 & - \\
\hline 2 & $\mathrm{pH}$ & 7.60 Jan. & 8.70 Jun. & 8.28 & $6.5-8.5$ \\
\hline 3 & $\begin{array}{c}\text { Conductivity }(\mu \mathrm{S} / \\
\mathrm{cm})\end{array}$ & 330 Aug. & 1060 Jun. & 601.25 & 300 \\
\hline 4 & & 26.0 Feb. & 200.0 Aug. & 83.58 & 5.0 \\
\hline 5 & Turbidity (NTU) & 458.0 Jan. & 675.0 Aug. & 564.58 & $250-600$ \\
\hline 6 & & 84.5 Aug. & 148.9 Jun. & 111.48 & 500 \\
\hline 7 & T.D.S. (mg/L) & $91.5 \mathrm{Jan}$ & 215.6 Jun. & 173.92 & $200-600$ \\
\hline 8 & T.H. (mg/L) & 14.5 Aug & 48.5 May. & 26.88 & $250-1000$ \\
\hline 9 & T.A. $(\mathrm{mg} / \mathrm{L})$ & 11.05 Aug & 29.75 Jun. & 22.25 & 250 \\
\hline 10 & $\mathrm{CI}(\mathrm{mg} / \mathrm{L})$ & $0.52 \mathrm{Jan}$ & 1.74 Aug. & 0.82 & 0.5 \\
\hline 11 & $\mathrm{SO}_{4}(\mathrm{mg} / \mathrm{L})$ & 0.38 Aug & 4.6 Jun. & 1.26 & 50 \\
\hline 12 & $\mathrm{PO}_{4}(\mathrm{mg} / \mathrm{L})$ & 6.0 Jun. & 8.53 Jan. & 7.45 & $2-6$ \\
\hline 13 & $\mathrm{NO}_{3}(\mathrm{mg} / \mathrm{L})$ & 3.25 Sep. & 12.00 Jun. & 7.71 & 3 \\
\hline 14 & $\begin{array}{l}\text { D.O. }(\mathrm{mg} / \mathrm{L}) \\
\text { B.O.D. }(\mathrm{mg} / \mathrm{L}) \\
\text { C.O.D. }(\mathrm{mg} / \mathrm{L})\end{array}$ & 10.85 Aug & 26.80 Jun. & 21.2 & 10 \\
\hline
\end{tabular}

Table No 1: Average values of recorded physico-chemical parameters of the Yamuna River and their Comparison with maximum permissible limit of W.H.O for drinking water

Total Alkalinity (T.A.): Maximum value (215.6 $\mathrm{mg} / \mathrm{L}$ ) of T.A. was recorded in month of June and minimum value $(91.5 \mathrm{mg} / \mathrm{L})$ in the month of January while average value was $173.92 \mathrm{mg} / \mathrm{L}$. Noticed T.A. value was below in half of time but more in half of the time of study than WHO recommended limit for drinking water (i.e., $200 \mathrm{mg} / \mathrm{L}$ ). T.A. of the Yamuna water was more than $100 \mathrm{mg} / \mathrm{L}$ in most of the time of study span thus it was suitable for fish culture.

Chloride (Cl): Chloride was varied from $14.5 \mathrm{mg} / \mathrm{L}$ to $48.5 \mathrm{mg} / \mathrm{L}$ and mean value was $26.88 \mathrm{mg} / \mathrm{L}$. Minimum chloride value was recorded in the August month while maximum in May month. Noticed chloride concentration was under the limit of WHO for drinking water (i.e., $250 \mathrm{mg} / \mathrm{L}$ ).

Sulphate (SO ): Minimum sulphate (11.05 mg/L) was recorded in the August month while maximum $(29.75 \mathrm{mg} / \mathrm{L})$ in June month. Average value of recorded sulphate was $22.25 \mathrm{mg} / \mathrm{L}$. Recorded values of sulphate concentration was under the lower limit (i.e., $250 \mathrm{mg} / \mathrm{L}$ ) prescribed by WHO for drinking water.
Phosphate (PO $)$ : Phosphate of Yamuna water was in the range of $0.52 \mathrm{mg} / \mathrm{L}$ (in January) to $1.74 \mathrm{mg} / \mathrm{L}$ (in August). Average value of recorded phosphate was $0.82 \mathrm{mg} / \mathrm{L}$. Recorded values of phosphate were beyond the permissible limit of drinking water (i.e., $0.50 \mathrm{mg} / \mathrm{L}$ ).

Nitrate (NO$)$ : Nitrate was recorded in range of $0.38 \mathrm{mg} / \mathrm{L}$ (in August month) to $4.60 \mathrm{mg} / \mathrm{L}$ (in June month) and average value of recorded nitrate was 1.26 $\mathrm{mg} / \mathrm{L}$. All recorded nitrate values were very low than the recommended limit of WHO for drinking water (i.e., $50 \mathrm{mg} / \mathrm{L}$ ).

Dissolved Oxygen (D.O.): The value of D.O. was ranged from 6.00 to 8.53 $\mathrm{mg} / \mathrm{L}$. Minimum value of D.O. was recorded in June month and maximum value in January. Average value of recorded D.O. was $7.45 \mathrm{mg} / \mathrm{L}$. Recorded D.O. values were satisfactory to good because in most time, it was more, than the prescribed limit of W.H.O. for drinking water (i.e., $6 \mathrm{mg} / \mathrm{L}$ ). It was good for fish culture.

\section{Biochemical Oxygen Demand} (B.O.D.): Maximum value (12.00 $\mathrm{mg} / \mathrm{L}$ ) of B.O.D. was recorded in month of June and minimum value $(3.25 \mathrm{mg} / \mathrm{L})$ in month of September with the average value of $7.71 \mathrm{mg} / \mathrm{L}$. Recorded B.O.D. range was more than the drinking water limit of B.O.D. prescribed by W.H.O. (i.e., $3 \mathrm{mg} / \mathrm{L}$ ).

\section{Chemical Oxygen Demand}

(C.O.D.): C.O.D. of the Yamuna water was varied in between $10.85 \mathrm{mg} / \mathrm{L}$ (minimum in August) to $26.80 \mathrm{mg} / \mathrm{L}$ (Maximum in June). The average value of recorded C.O.D. was $21.2 \mathrm{mg} / \mathrm{L}$. Noticed C.O.D. values was also more than the prescribed limit of WHO for drinking water (i.e., $10 \mathrm{mg} / \mathrm{L}$ ).

Biological Parameters: Observed selected four biological parameters were tabulated and analysed to understand the biological characteristics of studied water sample.

Phytoplankton: Registered Phytoplankton were belong to 35 species of 25 genera of different groups like as Chlorophyceae (12 species of 11 genera), Euglenophyceae (3 species of 2 genera), Bacillariophyceae (5 species of 5 genera) and Cyanophyceae (15 species of 7 genera). In the study period group Chlorophyceae was dominated over rest of the phytoplankton population. Data has given in Table No. 2.

By comparision of Palmer's algal index out of recorded 35 species of Phytoplankton, 15 species like as Euglena viridis, Oscillatoria limosa, $O$. tenuis, Scenedesmus quadricauda, Stigeoclonium tenue, Synedra ulna, Ankistrodesmus falcatus, Oscillatoria chlorina, Chlorella vulgaris, Cyclotella meneghiniana, Euglena acus, Phormidium 
uncinatum, Phacus caudatus, Navicula viridula and Microcystis aeruginosa are pollution tolerant. Presence of these species of algae (Phytoplankton) indicates organic pollution in water bodies. These species have been listed in Table No. 3 according to their Palmer's index serial (Palmer, 1969).
Daphnia sp. and Cyclops sp.. Along with 21 species of different group of Zooplankton Brachionus calyciflorus was also recorded. Presence of Brachionus calyciflorus is considered to be good indication of eutrofication (Sampaio et al., 2002). Data has given in Table No. 4.

\begin{tabular}{|c|c|c|c|c|c|}
\hline \multicolumn{3}{|c|}{ Chlorophyceae } & \multicolumn{3}{|c|}{ Bacillariophyceae } \\
\hline $\begin{array}{l}\text { S. } \\
\text { No. }\end{array}$ & Genera & Species & $\begin{array}{l}\mathrm{S} \\
\text { No. }\end{array}$ & Genera & Species \\
\hline 1 & $\begin{array}{l}\text { Ankistrodes- } \\
\text { mus }\end{array}$ & falcatus & 1 & Cyclotella & meneghiniana \\
\hline 2 & Chlorella & vulgaris & 2 & Melosira & sp. \\
\hline 3 & $\begin{array}{l}\text { Chlorococ- } \\
\text { cum }\end{array}$ & infusionum & 3 & Navicula & viridula \\
\hline 4 & Cladophora & fracta & 4 & Nitzschia & angustata \\
\hline 5 & Cosmarium & tenue & 5 & Synedra & ulna \\
\hline 6 & Closterium & $\mathrm{sp}$ & \multicolumn{3}{|c|}{ Cyanophyceae } \\
\hline 7 & $\begin{array}{l}\text { Hydrodic- } \\
\text { tyon }\end{array}$ & reticulatum & $\begin{array}{l}\text { S . } \\
\text { No. }\end{array}$ & Genera & Species \\
\hline \multirow[t]{2}{*}{8} & \multirow{2}{*}{$\begin{array}{l}\text { Pediastrum } \\
\text { Pediastrum }\end{array}$} & \multirow{2}{*}{$\begin{array}{l}\text { Simplex } \\
\text { tetras }\end{array}$} & 1 & Anabaena & \\
\hline & & & \multirow{3}{*}{2} & \multirow{3}{*}{$\begin{array}{l}\text { Lyngbya } \\
\text { Lyngbya } \\
\text { Lyngbya }\end{array}$} & \multirow{3}{*}{$\begin{array}{l}\text { gracilis } \\
\text { magnifica } \\
\text { spirulinoidus }\end{array}$} \\
\hline 9 & $\begin{array}{l}\text { Scenedes- } \\
\text { mus }\end{array}$ & $\begin{array}{l}\text { quadri- } \\
\text { cauda }\end{array}$ & & & \\
\hline 10 & Spirogyra & condensata & & & \\
\hline 11 & $\begin{array}{l}\text { Stigeoclo- } \\
\text { niưm }\end{array}$ & tenue & \multirow{3}{*}{3} & \multirow{3}{*}{$\begin{array}{l}\text { Merismopedia } \\
\text { Merismopedia } \\
\text { Merismopedia }\end{array}$} & \multirow{3}{*}{$\begin{array}{l}\text { elegans } \\
\text { punctata } \\
\text { glauca }\end{array}$} \\
\hline \multicolumn{3}{|c|}{ Euglenophyceae } & & & \\
\hline $\begin{array}{l}\text { S. } \\
\text { No. }\end{array}$ & Genera & Species & & & \\
\hline \multirow{2}{*}{1} & \multirow{2}{*}{$\begin{array}{l}\text { Eugelna } \\
\text { Euglena }\end{array}$} & \multirow{2}{*}{$\begin{array}{l}\text { acus } \\
\text { viridis }\end{array}$} & 4 & Microcystis & aeruginosa \\
\hline & & & 5 & Nostoc & $\mathrm{sp}$. \\
\hline 2 & phacus & caudatus & \multirow[b]{2}{*}{6} & \multirow{2}{*}{$\begin{array}{l}\text { Oscillatoria } \\
\text { Oscillatoria } \\
\text { Oscillatoria } \\
\text { Oscillatoria }\end{array}$} & \multirow{2}{*}{$\begin{array}{l}\text { clorina } \\
\text { limosa } \\
\text { subbrevis } \\
\text { tenusi }\end{array}$} \\
\hline & & & & & \\
\hline & & & 7 & $\begin{array}{l}\text { Phormidium } \\
\text { Phormidium }\end{array}$ & $\begin{array}{l}\text { calciola } \\
\text { uncinatum }\end{array}$ \\
\hline
\end{tabular}

\begin{tabular}{|l|l|l|}
\hline 1 & Euglena viridis & Euglenophyceae \\
\hline 2 & Oscillatoria limosa & Cyanophyceae \\
\hline 3 & O. tenuis & Cyanophyceae \\
\hline 4 & Scenedesmus quadricauda & Chlorophyceae \\
\hline 5 & Stigeoclonium tenue & Chlorophyceae \\
\hline 6 & Synedra ulna & Bacillariophyceae \\
\hline 7 & Ankistrodesmus falcatus & Chlorophyceae \\
\hline 8 & Oscillatoria chlorina & Cyanophyceae \\
\hline 9 & Chlorella vulgaris & Chlorophyceae \\
\hline 10 & Cyclotella meneghiniana & Bacillariophyceae \\
\hline 11 & Euglena acus & Euglenophyceae \\
\hline 12 & Phormidium uncinatum & Cyanophyceae \\
\hline 13 & Phacus caudatus & Euglenophyceae \\
\hline 14 & Navicula viridula & Bacillariophyceae \\
\hline 15 & Microcystis aeruginosa & Cyanophyceae \\
\hline
\end{tabular}

Table No 3: List of pollution tolerant species of recorded Phytoplankton in the Yamuna river at Kalpi in order of decreasing emphasis (Palmer, 1969).

Aquatic Macrophytes: In the study period various forms of aquatic macrophytes were observed and identified from different sampling stations of the Yamuna river at Kalpi. Identified plants belongs to 12 species of 11 genera includes in 8 families. Eichhornea, Potamogeton and Cyperus like aquatic Macrophytes along with other 8 genera were recorded. These Macrophytes indicates presence of high phosphate and nitrate in water bodies. Data has given in Table No. 5 .

Fish Fauna: Twenty nine species of fishes represents 21 genera of 10 families were observed and identified in the river Yamuna at Kalpi during course of study at selected sampling stations. Along with other 28 species of fishes Clarias batrachus like pollution indicator fish Table No 2: List of recorded phytoplankton in the Yamuna River at study was also recorded. Alam, (2013) reported 13 area (Kalpi)

Zooplankton: Registered zooplankton were belong to 22 species of 16 genera of different groups like as Protozoa ( 3 species of 3 genera), Rotifera (12 species of 6 genera), Cladocera ( 5 species of 5 genera) and Copepoda ( 2 species of 2 genera). Among recorded Zooplankton Rotifer's population was dominant during entire study span. Dominance of Rotifera is indicator of organic pollution. Pollution indicator species like Brachionus sp. and Keratella sp. were recorded along with clean water indicator sp. like species of fishes from Yamuna at Kalpi stretch (Jalaun,U.P.). IIT (s), (2012) have recorded 67 species of fishes belongs to 51 genera of 23 families in Auraiyya to Allahabad stretch of Yamuna river. Data of recorded fish fauna from river Yamuna at 4 sampling sites in Kalpi has given in Table No. 6.

\section{Conclusion}

On the base of over all hydrobiogical analysis and discussion it is clear that water quality of the Yamuna river at study area was not fit for drinking purpose but it was satisfactory for fish culture and irrigation 


\begin{tabular}{|c|c|c|c|c|c|}
\hline \multicolumn{3}{|c|}{ Protozoa } & \multicolumn{3}{|c|}{ Rotifera } \\
\hline No & Genera & Species & S.. & Genera & Species \\
\hline 1 & Arcella & dentata & 1 & Asplanchna & \\
\hline 2 & Paramecium & caudatum & \multirow{6}{*}{2} & \multirow{6}{*}{$\begin{array}{l}\text { Brachionus } \\
\text { Brachionus } \\
\text { Brachionus } \\
\text { Brachionus } \\
\text { Brachionus } \\
\text { Brachionus }\end{array}$} & \multirow{6}{*}{$\begin{array}{l}\text { calyciflorus } \\
\text { caudatus } \\
\text { falcatus } \\
\text { plicatilis } \\
\text { quadridentantu } \\
\text { rubens }\end{array}$} \\
\hline 3 & Vorticella & campanula & & & \\
\hline \multicolumn{3}{|c|}{ Cladocera } & & & \\
\hline Š & Genera & Species & & & \\
\hline 1 & Alona & rectangula & & & \\
\hline 2 & Bosmina & longirostris & & & \\
\hline 3 & Ceriodaphnia & reticulata & 3 & Filina & Longiseta \\
\hline 4 & Daphnia & carinata & \multirow{2}{*}{4} & \multirow{2}{*}{$\begin{array}{l}\text { Keratella } \\
\text { Keratella }\end{array}$} & \multirow{2}{*}{$\begin{array}{l}\text { cochlearis } \\
\text { tropica }\end{array}$} \\
\hline 5 & Moina & brachinata & & & \\
\hline \multicolumn{3}{|c|}{ Copepoda } & 5 & Philodina & citrina \\
\hline S. & Genera & Species & & Polyarthra & sp. \\
\hline 1 & Cyclops & $\begin{array}{l}\text { bicuspida- } \\
\text { tus }\end{array}$ & & & \\
\hline 2 & Marcrocylops & albidus & & & \\
\hline
\end{tabular}

Table No 4: List of Recorded Zooplankton in the Yamuna River at study area (Kalpi)

\begin{tabular}{|c|c|c|c|c|}
\hline $\begin{array}{l}\text { S. } \\
\text { No. }\end{array}$ & Family & Genus & Species & $\begin{array}{l}\text { Ecologica } \\
\text { Nature }\end{array}$ \\
\hline 1. & $\begin{array}{l}\text { Cerato- } \\
\text { phyllaceae }\end{array}$ & $\begin{array}{l}\text { Cerato- } \\
\text { phyllum }\end{array}$ & demersum & Submerged \\
\hline 2. & $\begin{array}{l}\text { Hydrochar- } \\
\text { itaceae }\end{array}$ & Hydrilla & verticillata & Submerged \\
\hline 3. & $\begin{array}{l}\text { Hydrochar- } \\
\text { itaceae } \\
\text { (Najada- } \\
\text { ceae) }\end{array}$ & Najas & minor & Submerged \\
\hline 4. & $\begin{array}{l}\text { Potamoge- } \\
\text { tonaceae }\end{array}$ & $\begin{array}{l}\text { Potamo- } \\
\text { geton } \\
\text { Potamo- } \\
\text { geton }\end{array}$ & $\begin{array}{l}\text { crispus } \\
\text { pectinatus }\end{array}$ & $\begin{array}{l}\text { Submerged } \\
\text { Submerged }\end{array}$ \\
\hline 5. & $\begin{array}{l}\text { Hydrochar- } \\
\text { itaceae }\end{array}$ & $\begin{array}{l}\text { Vallis- } \\
\text { neria }\end{array}$ & spiralis & Submerged \\
\hline 6. & Azollaceae & Azolla & pinnata & Floating \\
\hline 7. & $\begin{array}{l}\text { Pontede- } \\
\text { riaceae }\end{array}$ & $\begin{array}{l}\text { Eichhor- } \\
\text { nia }\end{array}$ & crassipes & Floating \\
\hline 8. & $\begin{array}{l}\text { Lemna- } \\
\text { ceae }\end{array}$ & Lemna & $\begin{array}{l}\text { paucico- } \\
\text { stata }\end{array}$ & Floating \\
\hline 9. & $\begin{array}{l}\text { Nympha- } \\
\text { ceae }\end{array}$ & $\begin{array}{l}\text { Nym- } \\
\text { phaea }\end{array}$ & sp. & Floating \\
\hline 10. & $\begin{array}{l}\text { Lemna- } \\
\text { ceae }\end{array}$ & $\begin{array}{l}\text { Spiro- } \\
\text { della }\end{array}$ & polyrhiza & Floating \\
\hline 11. & $\begin{array}{l}\text { Cypera- } \\
\text { ceae }\end{array}$ & Cyperus & esculentus & Emergent \\
\hline
\end{tabular}

\begin{tabular}{|c|c|c|c|c|}
\hline $\begin{array}{l}\text { S. } \\
\text { No. }\end{array}$ & Fish & Species & $\begin{array}{l}\text { Local } \\
\text { Name }\end{array}$ & Family \\
\hline 1. & Anabas & $\begin{array}{l}\text { testudin- } \\
\text { eus }\end{array}$ & Kabai/Jalebi & Anabantidae \\
\hline 2. & Barilius & barna & Ghilra & Cyprinidae \\
\hline 3. & Catla & catla & $\begin{array}{c}\text { Catla/Bosa/ } \\
\text { Bhakur }\end{array}$ & Cyprinidae \\
\hline 4. & Chagunius & chagunio & Chhagau & Cyprinidae \\
\hline \multirow{3}{*}{5.} & Channa & gachua & Girai/Bilaua & Channidae \\
\hline & Channa & marulius & Padam saur & Channidae \\
\hline & Channa & punctatus & Sauri/Gurrie & Channidae \\
\hline \multirow{2}{*}{6.} & Cirrhinus & mrigala & Nain/Mrigla & Cyprinidae \\
\hline & Cirrhinus & reba & $\begin{array}{l}\text { Raiya/Lah- } \\
\text { Kariya }\end{array}$ & Cyprinidae \\
\hline 7. & Clarias & batrachus & Mangur & Clariidae \\
\hline 8. & Cyprinus & carpio & $\begin{array}{c}\text { Common } \\
\text { Carp }\end{array}$ & Cyprinidae \\
\hline 9. & Esomus & danricus & Anjiara & Cyprinidae \\
\hline 10. & $\begin{array}{l}\text { Eutropi- } \\
\text { ichthys }\end{array}$ & vacha & Bachuwa & Schilbeidae \\
\hline 11. & $\begin{array}{l}\text { Hetero- } \\
\text { pneustes }\end{array}$ & fossilis & Singhi & $\begin{array}{l}\text { Hetero- } \\
\text { pneustidae }\end{array}$ \\
\hline 12. & $\begin{array}{l}\text { Hypop- } \\
\text { thalmic- } \\
\text { thys }\end{array}$ & molitrix & Silver Carp & Cyprinidae \\
\hline \multirow{4}{*}{13.} & Labeo & bata & Bata & Cyprinidae \\
\hline & Labeo & calbasu & $\begin{array}{l}\text { Karaunt/ } \\
\text { Calbasu }\end{array}$ & Cyprinidae \\
\hline & Labeo & gonius & Khursa & Cyprinidae \\
\hline & Labeo & rohita & Rohu & Cyprinidae \\
\hline 14. & $\begin{array}{c}\text { Masta- } \\
\text { cembelus }\end{array}$ & armatus & Bam & $\begin{array}{l}\text { Mastacem- } \\
\text { belidae }\end{array}$ \\
\hline \multirow{2}{*}{15.} & Mystus & tengara & $\begin{array}{l}\text { Chhota } \\
\text { tengra }\end{array}$ & Bagridae \\
\hline & Mystus & seenghala & Tengan & Bagridae \\
\hline \multirow{2}{*}{16.} & $\begin{array}{l}\text { Notop- } \\
\text { terus }\end{array}$ & chitala & Chital/Moya & $\begin{array}{l}\text { Notopteri- } \\
\text { dae }\end{array}$ \\
\hline & $\begin{array}{l}\text { Notop- } \\
\text { terus }\end{array}$ & notopterus & Patra & Notogpteri- \\
\hline 17. & Ompok & $\begin{array}{l}\text { bimacula- } \\
\text { tus }\end{array}$ & $\begin{array}{c}\text { Pabda/ } \\
\text { Jalkapoor }\end{array}$ & Siluridae \\
\hline 18. & Oxygaster & bacaila & Chelhua & Cyprinidae \\
\hline 19. & Puntius & sarana & $\begin{array}{l}\text { Putiyah/ } \\
\text { Khabda }\end{array}$ & Cyprinidae \\
\hline 20. & Rita & rita & Rita & Bagridae \\
\hline 21. & Wallago & attu & $\begin{array}{l}\text { Parhin/ } \\
\text { Lanchi }\end{array}$ & Siluridae \\
\hline
\end{tabular}

Table No 6: Recorded fishes from the Yamuna River at all sampling sites in Kalpi

purpose. Presence of both pollution tolerant and pollution intolerant species of biological parameters shows that this water was moderately polluted during Table No 5: List of recorded Aquatic Macrophytes in the Yamuna course of study.

river at study area (Kalpi)

Following measures could be applying to clean-up project for Yamuna river at the study area. 
1. Public awareness programmes for community participation in various Yamuna water quality restoration programme should be encouraged.

2. Segregation of domestic and industrial wastes and separate treatment scheme should be used for both type of wastes. Disposal of all type of garbage, solid and semisolid waste into the river Yamuna should be restricted.

3. All type of drainage like nala, sewer etc. should be diverted and using treatment plants before discharge of the waste water into the Yamuna river. Treated sewage water can be used for irrigation.

4. Maximum utilization of sewage treatment facilities, reduction of gap between waste water generation and its treatment.

5. Establishment of Combined Effluent Treatment Plant (CETP) is necessary for small industries effluent treatment and all the small scale industries (paper industries of Kalpi) should be connected with CETP(s).

6. Their should be some water pockets like pools in adjoining area of the river for washing of cloths, cattle bath and idols immersion etc.

7. Agricultural runoff from croplands might be checked by making boundary wall in surroundings of crop fields.

Manoj Kumar Shukla, holds MSc in Botany and PhD degree. He is, currently, a lecturer in Biology in R.S. G. U. Inter College, Kanpur, India. He has participated numbers of national seminar as well as presented and published numerous papers.

Corresponding E-mail: manojshuklacktd@gmail.com

Pushpendra Kumar Khare holds MSc in Botany and PhD degree. He is Assistant Professor at the Department of Botany in Government Maharaja $P$. G. Auto College, Chhatarpur, India. He holds MSc in Botany and PhD degree. His areas of research are related to Limnology, Environment and Ethnomedicine.

E-mail: pkkhare_20o7@yahoo.co.in

Ravindra Singh is a Associate Professor at Faculty of Science and Environment, Department of Biological Science. He holds PhD degree and his area of research are environmental botany, forest ecosystem management and remote sensing application in forest management. He has 25 years of teaching experiences. He has presented and published numbers of papers at national and international forum. He has published three books.

\section{E-mail: rsinghmgcgv@gmail.com}

\section{References}

Adoni, A.D. (1985). Work book on limnology, Pratibha Publications Sagar (M.P).

Agrawal, S. and Trivedi, R.C. (1995). Ecological analysis of the river Yamuna- a Functional Approach

in a Diversified Ecosystem in India, Arch. Hydrobiol. Suppl., o945-3748/95/o101: 405-426p.
Alam, S.K. (2013). Hydrobiological and Physico-chemical analysis of the river Yamuna at Kalpi distt. Jalaun U.P. India, Ph.D. Thesis (Zoology) submitted to B.U. Jhansi.

APHA, (2005). Standard method for the estimation of water and waste water, 21st Ed., Washington DC.

Battish, S.K. (1992). Fresh water zooplankton of India, Oxford and IBM publications.

Bodola, S.P. and Singh, H.R. (1981). Hydrobiology of river Alaknanda of Garhwal Himalaya, Indian J. of Eco., Vol. 8: 269-276.

Chandra, M., Saxena, R.S. and Sharma, H.N. (2014). Hydrobiological studies in river Burhi Ganga in dristict Etah (U.P.), J. Adv. Lab. Res. In Bio., Vol. V (iii): 102-106, ISSN 0976-7614.

IIT(s), (2012). Floral and Faunal Diversity in Yamuna River (Yamunotri to Allahabad) under the GRB EMP

(Ganga River Basin Environmental Management Plan): 1-48.

Jhingran, V.G. (1992). Fish and Fisheries of India, Hindustan Publishing Corp., New Delhi.

Jayram, K.C. (2010). The fresh water fishes of the Indian Region, Narendra Publishing House, Delhi, 616.

Mishra, A., Mukharjee, A. and Tripathi, B.D. (2009). Seasonal and Temporal Variation in physico-chemical and Bacterio-logical characteristics of river Ganga in Varanasi, Int. J. of Env. Res., Vol. 3 (3): 395-402.

Palmer, C.M. (1969). A composite rating of algae tolerating organic pollution. J. Phykol., 5:78-82.

Prescott, G.W. (1962). Algae of the Western Great Lakes Area, W.M.C.

Sampaio, E.V., Rocha, O., Tundisi, T.M. and Tundisi, J.G. (2002). Composition and abundance of Zooplankton in the limnetic zone of seven reservoirs of the Paranapanema river, Brazil, Brazil Journal Biology 62 (3): 525-545.

Sengupta, B. (2006). Water quality status of River Yamuna (1999-2005) Central Pollution Control Board, Delhi. Assessment and Development of River Basin Series: ADSORBS/41/2006-07.

Sharma, M.P., Shinghal, S.K. and Patra, S. (2008). Water quality profile of Yamuna River, HYDRONEPAL, Issue No. 3: 27-32 pp.

Singh, A.P. and Gosh, S.K. (1999). Water quality of river Yamuna, Poll. Res., 18 (4): 435-439.

Singh, R.K. and Singh, K.N. (2007). Physico-chemical and biological analysis of Gomti river water affected by Urban wastes, Mar. Sc. Res. India, Vol. 4(2): 233-236.

Shukla, S.C., Tripathi, B.D., Kant, R., Depa, K.V. and Pandey, V.S. (1989). Physico-chemical and biological characteristics of river Ganga from Mirzapur to Ballia, Ind. J. Env. Hlth., 31 (3): 218-227.

Trivedi, R.K. and Goel, P.K. (1986). Chemical and Biological methods for water pollution Studies, Env. Publisher Karad, 2nd Ed, 415110, India.

Whitton, B.A., Rott. E. and Friedrich, E. (1991). Methodological aspects and perspectives in the use of periphyton for monitoring and protecting rivers. Use of algae for monitoring rivers. Institute for Botanik, University of Innsbruck, p. 9-16. 